\title{
When scientists turn against science: exceptionally flawed analysis of plant breeding technologies
}

\author{
Deepak Pental \\ Centre for Genetic Manipulation of Crop Plants, University of Delhi South Campus, Benito Juarez Road, New Delhi 110021 , India
}

Kesavan and Swaminathan have written three articles in 2018 dealing with the issues of food and nutritional security, sustainable agriculture and climate change, and provided in their own words a 'proactive analysis' of the available breeding technologies to meet these challenges. Almost every important issue related to agriculture has been touched upon. However, these reviews neither accurately state the history of plant breeding nor make any evidence-based analysis of the new developments in the area of genomics and genetic engineering to meet some of the critical challenges in crop breeding. The authors' averments on genetically engineered (GE) crops completely align them with the position of overzealous environmentalists and ideologues, who have been campaigning against the use of GE technologies in crop breeding. The authors have distorted the history of plant breeding, rejected emerging consensus on the safety of GE crops, and suggested solutions that are grossly inadequate to meet the challenge of low-input, high-output agriculture. I analyse here most of the themes that the abovementioned two authors have addressed and provide reasoning for a complete rejection of their analysis.

Keywords: Agriculture, anti-science disposition, climate change, genetic engineering, plant breeding.

KESAVAN and Swaminathan have recently published three articles on critical issues of sustainable agriculture, food and nutritional security ${ }^{1-3}$. In the first article ${ }^{1}$, the authors have reminded the readers of the UN Sustainable Development Goals (SDGs) - particularly Goal 2 - 'End hunger, achieve food security and improve nutrition and promote sustainable agriculture', and outlined some social and scientific strategies to achieve the same. An involved reading of the article would, however, show that under the pretext of addressing a lofty goal, the authors real aim was to perpetrate an attack on technologies of plant breeding - both old and new. In the second article ${ }^{2}$, they make sweeping statements on the performance of limited number of genetically engineered (GE) crops that have been released globally and seem to speak the language of evangelical environmentalists and ideologues of

e-mail: dpental@gmail.com many hues, who have been quite successfully blocking the use of recombinant DNA-based GE technologies in plant breeding. In the third article ${ }^{3}$, the authors have dismissed with an imperial disdain, almost all the achievements of science and technology (S\&T) in feeding the present global population of 7.3 billion.

Through these three articles, Kesavan and Swaminathan have unequivocally aligned themselves with overzealous environmentalists and ideologues, who have mindlessly attacked the use of GE technology to improve crops for achieving low-input, high-output agriculture low in terms of both monetary inputs and natural resource inputs - to meet the food and nutritional needs of a global population that is predicted to peak out at 11.2 billion. Their 'proactive analysis' of modern breeding technologies $^{3}$ is a reflection of their ideological proclivities; it is not a serious scientific analysis. If unchallenged, their averments can cause serious damage to the efforts towards achieving sustainable agriculture and food and nutritional security through research and development (R\&D). In this write-up, I point out deep flaws in their analysis of the technologies of plant breeding and argue that only an open stance on the role of S\&T will allow achieving the SDG Goal of sustainable agriculture, and food and nutritional security in a world of increasing population, stress on natural resources and climate uncertainties.

\section{Prescribing the most inadequate technologies for sustainable agriculture}

In their assessment of breeding technologies for sustainable agriculture, only two technologies receive unequivocal support - polyploid breeding and mutation breeding ${ }^{1,3}$. In polyploid breeding, Kesavan and Swaminathan cite the example of a human-made polyploid - triticale, a crop containing genomes of both rye and wheat. Triticale, in spite of being around for more than a 100 years, is currently grown only in around 4.2 million hectares $(\mathrm{m} \mathrm{ha})^{4}$, mostly in the cold regions of the world as an animal feed crop. Contrary to the authors' claim, the crop is hardly grown in Africa; only 17,000 ha in 2016. The initial intentions behind using triticale as a more hardy cereal crop should not be faulted, as proposing and testing new ideas 
is the bedrock on which S\&T is built; but triticale is a failed experiment. Compared to $4.2 \mathrm{~m}$ ha globally under triticale, the crop it was supposed to replace, wheat, was grown in around $220 \mathrm{~m}$ ha in 2016.

Another favourite technology of Swaminathan and Kesavan is mutation breeding. Natural mutations are the primary source of variability and therefore, organic evolution. The other significant source of variability is genetic recombination. The authors suggest that induced mutation breeding using $\mathrm{X}$-rays and gamma rays or chemical agents 'is clearly the most sustainable from ecological, social and economic point of view for enhancing productivity'. Contrary to what the authors suggest, mutation breeding is a messy method of plant breeding. All the suggested mutagenic agents induce multiple mutations in the genome - it takes years to clean up the material and separate a desirable mutation from sundry mutations, which if retained would cripple the yield potential of the target crop. Since mutations are mostly deleterious, mutation breeding programmes in crops invariably included crosses of mutagenized material with elite lines and varieties. In such mixed breeding activities, it is seldom clear what is the contribution of the induced mutations and what has been derived by recombination in the final released varieties. Mutation breeding became popular in the 1960s and 1970s in the developing countries like China and India; the technique went out of fashion by the 1980s. Mutation breeding in crops has at best provided some null mutants for removing antifeedants and maybe some early flowering material, but nothing more. In an assessment of crop breeding technologies, this is what a leading plant breeder - N. W. Simmonds ${ }^{5}$ had to say in 1991 on mutation breeding: 'This useless, even baneful, activity goes back to Hermann Muller's important work on Drosophila genetics in 1927. Muller richly deserved the Nobel Prize he got but it was others, not Muller, who reckoned they were going to revolutionize plant breeding. In the plant breeding context, it has generated mountains of mostly disreputable literature, some trivial ornamental mutants and nothing of any practical consequence'. Twenty-five years later, Rex Bernardo ${ }^{6}$ in a review of breeding methodologies has fully endorsed this conclusion.

\section{Some real miracles in plant breeding that have fed the world}

The real miracle in yield increase in the 20th century happened through the use of dwarfing genes and hybrids in cereal crops ${ }^{7,8}$. It would be most pertinent to cite the example of wheat breeding through the use of the dwarfing genes, also referred to as the Rht (reduced height) genes ${ }^{9}$. Dwarf wheat, in all probability, originated in Korea and was taken to Japan during the KoreanJapanese War in the 16th century. Japanese breeders used Rht 8 containing lines to breed a dwarf variety, Akakao- mugi and later developed dwarf varieties like Norin10 containing the dwarfing genes Rht 1 and Rht 2. Rht 8 made its way to Italy after the First World War and was used for breeding higher-yielding winter wheat varieties which later spread to central Europe, increasing wheat yields from 1.3 tonne/ha in 1930 to 5.2 tonne/ha by the 1980s (ref. 9). Dwarf wheat Norin10, developed by breeder Gonjiro Inazuka, was released for cultivation in Japan in 1935 (ref. 10). This variety caught the attention of Cecil Salmon, a USDA scientist assisting US occupation forces in Japan after the Second World War. The material was sent to breeder O. A. Vogel at the Washington State University at Pullman, USA, who incorporated the dwarf trait into American spring wheat. Norin 10 and other materials with the dwarfing genes were used by Norman Borlaug at CIMMYT, Mexico, to develop varieties, which besides the dwarf character were photoperiodinsensitive and disease-resistant ${ }^{11}$. The CIMMYT wheat breeding programme saved Mexico from an imminent food crisis. In 1965, with famine-like conditions prevailing in North India, Mexican varieties were tested for the first time in the country and two of these - Lerma Rojo 64 and Sonora 64 -were found to out-yield the best Indian lines ${ }^{12}$. These varieties were grown more extensively in 1966, through a large-scale import of seeds of the two varieties. This was the beginning of the Green Revolution in India.

A similar miracle happened in rice. During the 1960s and 1970s, Henry Beachell and other breeders at IRRI, Philippines, screened thousands of germplasm lines and crosses to develop the first dwarf variety IR-8 containing dwarfing gene $(s d 1)$ from a Chinese line called Dee-geowoo-gen ${ }^{7,8,13}$. This was followed by other IR series of varieties developed by Gurudev Khush and other breeders incorporating disease resistance and many other agronomic traits from unadapted germplasm through recombination breeding. Breeders in India have extensively used the rice dwarfing gene to develop high-yielding varieties adapted to different regions of the country.

The story of wheat breeding and many other selfpollinating crops like rice unequivocally shows that the most crucial technique in plant breeding so far has been recombination breeding using the natural variability present in the germplasm - and not mutation breeding. To cite an example from India - the Mexican wheat varieties, although high-yielding, had an undesirable attribute - their seed was red, the grain of the traditional Indian wheat varieties used for chapatti-making was amber in colour and preferred by the consumers. Both recombination and mutation breeding were tried to develop amber-coloured varieties. The mutation-based line, Sharbati Sonara never took off, but varieties like Kalyansona and Sonalika were successfully developed through recombination breeding using the high-yielding Mexican wheat lines and soon replaced the original Mexican varieties $^{12,14}$. 
Kesavan and Swaminathan also refuse to acknowledge the contribution of hybrid breeding in feeding the world. Hybrid breeding is the second most important development of the 20th century after systematic pure-line breeding. Till 1936, maize yields in USA were around 1.6 tonne/ha. The yield started to increase only after hybrids were introduced; currently, maize hybrids yield around 10.9 tonne/ha in $\mathrm{USA}^{4}$. More recently, China has raised yield potential of rice to more than 10 tonne/ha through hybrids ${ }^{15}$. Swaminathan records that as the Director General of IRRI, he helped China in establishing four rice research institutes - one of these at Changsha was dedicated to hybrid rice breeding ${ }^{16}$. However, in their recent article, Kesavan and Swaminathan ${ }^{3}$ have no good word for hybrid technology as 'farmers have to buy hybrid seed afresh every year. Such technologies provide opportunities for the corporate sector to produce hybrid seed for sale at considerable profits'. The conclusion is neither based on scientific nor any sound economic analysis; it is an ideological stance.

Dwarfing genes of wheat and rice were saviors of the humankind; use of the dwarfing genes made the food situation comfortable in the Western countries, and helped South Asia and many other parts of the world in wardingoff famines and resultant political instability. The global population increase was precipitated by a health revolution - drugs, vaccines, diagnostics, advances in medicine and better hygiene. The Green revolution only saved humanity from starvation. Kesavan and Swaminathan slam almost every development in the area of agriculture as unsustainable - what about the consequences of the health revolution?

\section{Yield protection is even more critical than yield increase}

A constant threat from pests and pathogens looms over all the biological species. Host-pest/pathogen competition for survival described as an 'arms race' in evolutionary biology is a major driving force in organic evolution. So much so that sexual reproduction which generates variability through genetic recombination by shuffling of the genes is considered - in all probability - to have originated and selected for due to the 'arms race'. Genome sequencing of almost all the major crops and many plant species ${ }^{17}$ has shown that plant genomes have undergone repeated rounds of polyploidy, genome enlargement and shrinkage, and contain a large number of resistanceconferring $R$-genes and their allelic variants at the population level ${ }^{18,19}$. Plants are also full of secondary metabolites that discourage herbivory and invasion by pathogens. Crop species have gone through many genetic bottlenecks - first at the time of domestication, later on with human migrations and more recently, due to intensive selection for yield increase ${ }^{20}$. This has reduced allelic variation for the $R$-genes and made crops vulnerable to diseases. Large-scale cultivation of major crops under homogenous agronomic conditions and lack of crop rotation encourage rapid multiplication of crop pests and pathogens. In 2003, we did a survey amongst plant breeders to find the most crucial breeding objectives in the major crops grown in India; pests and pathogens topped the list of the identified objectives for $R \& D^{21}$.

Keeping crops free of pests and pathogens is, therefore, a major challenge. In all the three articles ${ }^{1-3}$, Kesavan and Swaminathan after suggesting low-impact technologies for yield increase, go on to slam $B t$ cotton. As a recap, $B t$ cotton contains a gene from the bacterium, Bacillus thuringiensis, that encodes an insecticidal protein that is effective against some of the most devastating lepidopteran pests of cotton, including American bollworm Helicoverpa armigera. Development of $B t$ cotton required three technologies - recombinant DNA technology, ability to regenerate plants from somatic cells in vitro and agrobacterium-based genetic transformation vectors. $B t$ cotton, therefore, is a fine example of what GE technologies can achieve in solving some intractable breeding objectives, like conferring resistance to insect pests. In 2002 , when $B t$ cotton was officially released in India, the country was staring at failing cotton crops - in spite of very heavy use of insecticides. $B t$ cotton gave a major fillip to cotton cultivation; from being an importer, the country has become once again an exporter of cotton fibre $^{22}$. Several studies have shown that farmers and the economy have immensely benefited from $B t$ cotton $^{23}$.

Kesavan and Swaminathan cite resistance development in one of the insect pests of cotton - pink bollworm to $B t$ cotton to claim - 'Experience of three decades has shown that pests develop resistance sooner than later'. It is projected as if resistance development is specific to the GE methods of introducing resistance-conferring genes. The fact is that pests and pathogens develop resistance to both chemical pesticides and gene-based solutions, irrespective of the source of the genes. Resistance development is, therefore, inevitable. The challenge is to delay the development of resistance in pests and pathogens, and generate solutions for imparting durable resistance in the crop species. For Bt crops, population geneticists had insisted upon 'high expression' of the insecticidal proteins and a 'refugia' of non-Bt plants to prolong the effectivity of the insecticidal proteins genes ${ }^{24,25}$. Resistance development in pests can also be slowed down by deploying in the crop new genes that work through different mechanisms of imparting resistance. Padmanaban ${ }^{26}$ rightly called Kesavan and Swaminathan's analysis of $B t$ cotton as superficial.

As with the issue of yield increase, for yield stability also Kesavan and Swaminathan avoid mentioning any R\&D efforts on managing pests and pathogens of major crop plants. A fact everyone needs to know and appreciate is that some of the major crops like rice and wheat 
have been protected from fungal and bacterial pathogens by stacking resistance-conferring $R$-genes from landraces and related species of these crops ${ }^{27,28}$. Extensive R\&D at the global level has kept wheat free of the dreaded rust diseases and rice from bacterial blight and blast disease. Resistance to pests and pathogens has been and will remain a major research imperative for sustainable agriculture. Only S\&T can provide more durable solutions in protecting crops from pests and pathogens. Genetic engineering technologies allow gene sourcing from a wider gene pool and also help in avoiding the problem of linkage drag in transferring genes from the wild relatives to crop plants. We now have the opportunity to restore the allelic diversity lost during the domestication of the crops and significantly reduce the use of chemicals for crop protection, but Kesavan and Swaminathan are oblivious of these new possibilities and opportunities.

\section{Misplaced criticism of GE mustard}

Kesavan and Swaminathan ${ }^{3}$ also pick GE mustard developed by our group at the University of Delhi for their brand of 'proactive analysis'. Unfortunately, there is no original analysis here. Almost all the points echo accusations made by anti-GE technology activists. A response to such accusations has already been given in a report by the National Academy of Agricultural Sciences $(\mathrm{NAAS})^{29}$. To quote from the report: 'Ever since the Government of India activated decision making process by the regulatory bodies - hardcore GM technology bashers have been very active in spreading lies and fears on GM crops - particularly mustard. In some recent writeups - GM bashers have tried to show that the opposition to the release is based on scientific data. Such arguments are open to analysis. President, NAAS, requested R. B. Singh (past-President NAAS) and a few other colleagues to analyse the arguments put-forth by GM bashers purely from a scientific perspective. The broad conclusion is that almost all the negative reports on GM mustard appearing on websites, newspapers and letters to the Ministers and Prime Minister's Office are fallacious, wilfully distort scientific data and have been made with the sole intention of scuttling the use of a technology which could be of great interest and value to the country ${ }^{29}$. The complete report is available at the NAAS website.

Kesavan and Swaminathan have avoided referring to the NAAS report in their review. Instead, they have tried to provide legitimacy to the falsehoods of activists by repeating their arguments in the review. Hybrid seed production requires two components - a pollination control mechanism and parents (also called combiners) that when crossed, provide hybrid seeds which give more productive crop in the farmer's field. In most of the flowering plant species, male and female organs are present in the same flower and in several crop species, pollen of the same flower can pollinate and fertilize the female part. This selfing has to be avoided for the development of hybrid seeds. For this, one of the two parents has to be made male sterile. A male sterile line will produce seeds only with the pollen of the other parent. However, the pollen-donor parent must contain a function that restores male sterility, so that hybrids grown in the farmer's field are fully fertile. A GE technology-based pollination control system, using the barnase gene (for male sterility) and barstar (for fertility restoration) was initially developed by Plant Genetic Systems (PGS) in Belgium ${ }^{30,31}$ and deployed in rapeseed (also known as Canola) - a sister crop of mustard. Transgenes only express in the anther (male part) tissues. This GE technology-based system has been used extensively to develop hybrids in rapeseed since 1996 in Canada and later in USA and Australia. Millions of tonnes of oil and meal extracted from GE rapeseed have been consumed-oil by the humans and meal by the livestock, including in India. No untoward effects have been recorded so far.

We had earlier shown that hybrids between the Indian and East European gene pool lines of mustard are heterotic for yield ${ }^{32}$. Extensive research was carried out by our group and at the Indian Agricultural Research Institute on developing a CMS (cytoplasmic male sterility - encoded by the mitochondrial genome)-based system for hybrid seed production in mustard. Most of the CMS systems were found to be inadequate for large-scale seed production - as these either had yield penalties or suffered from inadequate restoration of fertility. We used the GE method developed by PGS with some modifications ${ }^{33,34}$. The barnase and barstar gene containing lines - Varuna bn 3.6 (Indian gene pool line) that is male sterile and $\mathrm{EH}-2$ mod bs 2.99 (an East European gene pool line) that restores fertility make a versatile system for hybrid seed production in mustard. The GE parental lines, their normal comparators and the first transgenic hybrid DMH-11 $($ Varuna $\times$ EH-2) were subjected to all the biosafety tests stipulated by the Government of India (GoI) and were found to be safe for environmental release by the Genetic Engineering Appraisal Committee (GEAC) in the Ministry of Environment, Forests and Climate Change, New Delhi according to the minutes of the 133rd meeting of the GEAC held on 11 May 2017. However, a decision on the release by the Government of India is still awaited. DMH-11 is the first-generation hybrid and higher yielding than the released pure-line varieties. Better hybrids with disease resistance, oil and meal-quality traits and even higher yield will follow, as is the case in any hybrid breeding programme. Our group alone has published around 60 research papers on mustard breeding using both conventional and so-called modern approaches. There are other competent groups also working on mustard in the country. I would predict that within $8-10$ years of the release of the barnase/barstar system for hybrid seed production, the average yield of mustard will double 
in the country. And that will make all the activists look so unreasonable - therefore, all the fear-mongering and desperation amongst anti-GE technology activists and unfortunately some scientists as well to scuttle the release of a versatile technology for hybrid seed production.

\section{The 2004 report and current position of the authors}

Repeated references have been made in the three articles ${ }^{1-3}$ to the 'Report of the Task Force on the Application of Agriculture Biotechnology by Dr M. S. Swaminathan, May 2004' (ref. 35) as 'the document' which should be followed in setting up the agenda for agriculture biotechnology. One of the major recommendations in the report was: 'High priority should be accorded in transgenic approach to the incorporation of resistance to insect pests and diseases including viruses and to drought and salinity (i.e. biotic and abiotic stresses).' Amongst the prioritized target traits in crop plants, resistance to insect pests and diseases was mentioned as one of the top priorities. Engineering male sterility for breeding hybrids was also listed as high priority ${ }^{35}$. The three articles ${ }^{1-3}$ published in 2018 do not provide any evidence that has brought about a change of mind on these priorities.

In 2013, three scientists, viz. Marc Van Montagu of Belgium, and Mary-Dell Chilton and Robert Fraley of USA, who made seminal contributions to the field of plant genetic engineering were conferred with the World Food Prize (the fourth, Jeff Schell had unfortunately passed away). Speaking at the ceremony Swaminathan had this to say ${ }^{36}$ : 'I am particularly happy that on the 60th anniversary of the discovery of the double-helix structure of the DNA molecule, three very eminent biotechnologists ... have been recognized for their work and they will be receiving the World Food Prize. It is very appropriate because I think the science of genetic engineering, the new biology, and new genetics, has certainly opened up completely new opportunities.' It is not clear from the three articles ${ }^{1-3}$ as to what new evidence has emerged in the past five years for such a dramatic shift in the authors' position on GM technologies.

The concept of regulatory precautions around genetic engineering was first suggested by scientists only. At the famous Asilomar Conference in 1975, some of the leading figures in molecular biology and the emerging area of recombinant DNA felt that the new technologies of gene manipulation and their transfer across divergent organisms need some regulatory oversight ${ }^{37}$. However, some valid concerns and sound advice from the scientists on the issue of containment of potentially pathogenic microorganisms were over blown by the environmental movements, whose primary concern till then was on the use of agrochemicals. In the past couple of years, very involved review of GE technologies and released transgenic crops by the National Academy of Sciences, USA ${ }^{38}$; American Association for the Advancement of Science ${ }^{39}$; the Royal Society, London ${ }^{40}$; the African Academy of Sciences ${ }^{41}$; European Academies Science Advisory Council ${ }^{42}$; American Medical Association ${ }^{43}$; Union of German Academics of Science and Humanities ${ }^{44}$, and even the European Commission $^{45}$ - besieged by strong anti-GM lobbies in Europe, has come to the conclusion that the GM crops are not per se more risky than conventional plant breeding technology.

Kesavan and Swaminathan obviously have no value for this emerging scientific consensus on the safety of GE technologies. Instead, they have chosen to make unscientific assertions like - 'recombinant DNA technologies use stressful processes', 'adding a gene from outside into recipient genome increases the DNA content of the cell from outside', 'HT transgenic mustard, if commercialized could lead to genetic pollution of an extremely rich biodiversity of the genus Brassica, and the havoc that "Brassica" superweed species would cause to thousands and thousands of resource-poor farmers would be far beyond control and restoration', 'development of transgenic BT and HT crops ultimately chose the illiterate and resourcepoor farmers - to put blame on them', 'form of agriculture needed to sustain food and nutritional security for the present and the future has to be eco-friendly as well as pro-women, pro-poor and pro-livelihood oriented', and the conclusion 'In the design of farming system for nutrition, the genetically engineered crops should be avoided as these are known to produce "unintended effects" and moreover, these are neither pro-nature, nor pro-poor, nor pro-woman'. None of the assertions is scientific; almost all are ideological, the tone and tenor being the same as that of the anti-GE environmentalists. The onslaught by anti-GE activists has been tragic for the global food security ${ }^{46}$; but when scientists avoid evidence and facts and try to scuttle scientific progress, the consequences can be even more damaging.

\section{Anti-science disposition}

It is important to recall here an anti-science episode that happened in the erstwhile Soviet Union. Nikolai Vavilov was one of the greatest geneticists of the last century ${ }^{8,47}$. He identified the centres of origin of most of the crop species grown around the world and over a period of 20 years, 1916 onwards, collected enormous germplasmmore than any other person in human history. He was passionately committed to the improvement of crop productivity in his country through the use of germplasm and recombination breeding. In the 1930 s, Soviet Union saw the rise of a maverick scientist Trofim Lysenko ${ }^{48}$, who wilfully 'confused' the epigenetic phenomenon of 'vernalization' - cold treatment to the seeds of winter wheat allowed it to be grown in the spring season for achieving 
higher production - as a general prescription for adapting crops to abiotic stresses through physiological conditioning. His Lamarckian views were enticing for Joseph Stalin, who saw the idea of 'better crops' through physiological conditioning fit into communist thinking of creating a 'new man' through cultural conditioning. In a purge, most of the crop geneticists were sent packing. Vavilov was imprisoned in Siberia where he died, most probably of starvation. Besides collectivism, destruction of the science of genetics and plant breeding was a major reason for the poor performance of Soviet agriculture.

However, Kesavan and Swaminathan do not propose a complete ban on GE technologies. Instead, Swaminathan has been quoted in one of the articles ${ }^{3}$ for the suggestion that 'genetic engineering must be need-based. Only in very rare circumstances (less than $1 \%$ ) may there arise a need for the use of this technology'. Who will decide this $1 \%$ ? Kesavan and Swaminathan have already condemned GEAC scientists for having a conflict of interest. NAAS reports do not impress them. Is this $1 \%$ going to be decided by anti-GE activists and assorted ideologues? The $1 \%$ formula is an utterly illiberal, anti-science and antiprogress idea that should be rejected entirely not only by the scientific community, but also by the society at large.

\section{Challenges and opportunities}

Kesavan and Swaminathan draw attention to global warming and remind the readers that global warming of about $1.5^{\circ} \mathrm{C}$ will be the tipping point for major disasters to ensue. Climate-resilient agriculture will require human ingenuity at its best and rational management of resources. They suggest that the challenge of climate change can be met by shift from chemical intensification to a 'sustainable intensification' of inputs with 'biological software'. Unfortunately, their 'biological software' only includes 'biopesticides and biofertilizers', and does not include genes.

Developments in biological sciences during the last 40 years have given us extensive biological software - molecular markers for more efficient selection of recombinants, a vast repertoire of genes and their promoters for expression modulation (most of the crop genomes and in some cases even their wild relatives have been sequenced) and GE methodologies ${ }^{49}$ to tackle the challenges unmet with conventional recombination breeding. Astounding progress has been made in plant genome sequencing; the third-generation sequencing technologies allow chromosomal-level genome assemblies at very low $\operatorname{costs}^{50}$. There are more precise alternative methods available for Kesavan and Swaminathan's favourite technique of mutagenesis - these are Tilling and more recently, CRISPR/Cas.

The global population has risen from 1.6 billion in 1900 to 7.3 billion in 2018. Average life span in India in
1900 was 23 years; today it is 67 years. The medical revolution of the last century saved millions of lives, but who fed them? At the dawn of the 20th century, even the most advanced countries of Europe were facing starvation - the much riled Haber-Bosch process of producing nitrogen fertilizers saved the highest number of lives in history - around 2.7 billion $^{51,52}$. Of course, some sadistic environmentalists will consider this discovery to be the disaster that allowed human population to expand. In spite of all the developments in farm management, fertilizers, agrochemicals and plant breeding, nearly 70 million people perished in famines in the last century ${ }^{53}$. Food and nutritional security should not be taken lightly.

Since 1947 when India became independent, many countries of East Asia which embraced S\&T more systematically and industrialized, moved out of the poverty trap quickly and as a result, their populations stabilized. We could not move at that pace. A large chunk of the Indian population is still stuck in the poverty trap. In spite of an overall improvement in nutrition and calorie uptake, hunger still stalks a large section of our people. The percentage of undernourished has come down and so have the child mortality rates; but we still have a long way to go. In the early 1990s, prevalence of wasting in children under the age of five years was around $20 \%$; in 2016 , the percentage remained the same ${ }^{54}$. Let us face some stark realities - if our children eat well and millions who do not have adequate food intake also eat well, with a population that is expected to reach 1.6 billion in 2050 , and count in addition climate uncertainties and freshwater shortages that the country is already experiencing-thechallenges for Indian agriculture are immense. A continuous wheat-rice cultivation cycle in the north and multiple rice crops in the south are exhausting groundwater resources. Hardly any attention is being given to conservation tillage and crop rotation - the two most fundamental practices for sustainable agriculture. Yields of oilseed, legume and coarse grain crops are stagnating at around 1 tonne/ha. Many crops are highly vulnerable to pests and pathogens, and will require protection either with more benign agrochemicals or by gene-based solutions. Involved breeding work is required for developing rice that has high yield but much lower water requirement, wheat varieties that will yield high even under terminal-stage heat stress and maize that can withstand flooding. Meeting such challenges will require the use of all the appropriate technologies, including GE technologies. There is a need for higher public spending on R\&D and open-source knowledge generation, which will keep the cost of the seed within the reach of the small and marginal farmers.

Rather than exhorting the scientific community to excel in agricultural R\&D and calling upon the government for an increase in financial support for agricultural research, Kesavan and Swaminathan are pandering to ideologues who are sold to vague ideas of 'naturalness', 'genetic pollution', 'playing with nature', 'natural food' 


\section{REVIEW ARTICLE}

and even 'spiritual agriculture'. All that they have to offer are homilies like - 'internet-based lab-to-land, lab-to-lab, land-to-lab and land-to-land linkages' as a solution. The internet does not provide solutions, it only spreads them faster. The Indian farmer is intelligent, whenever S\&T has and will provide farmers with robust solutions to enhance crop productivity and save natural resources, they will grab the developments and run with them.

1. Swaminathan, M. S. and Kesavan, P. C., Science for sustainable agriculture to achieve UN SDG Goal 2. Curr. Sci., 2018, 114, 1585-1586.

2. Kesavan, P. C. and Swaminathan, M. S., Three decades of experience with genetically engineered crops: way forward in the Indian context. Sci. Cult., 2018, 84, 92-97.

3. Kesavan, P. C. and Swaminathan, M. S., Modern technologies for sustainable food and nutrition security. Curr. Sci., 2018, 115, 1876-1883.

4. http://www.fao.org/faostat/en/\#home

5. Simmonds, N. W., Bandwagons I have known. TAA Newsletter, Tropical Agriculture Association, 1991.

6. Bernardo, R., Bandwagons I, too, have known. Theor. Appl. Genet., 2016, 129, 2323-2332.

7. Murphy, D., Plant Breeding and Biotechnology: Societal Context and the Future of Agriculture, Cambridge University Press, Cambridge, UK, 2007.

8. Kingsbury, N., Hybrid: The History and Science of Plant Breeding, University of Chicago Press, Chicago, USA, 2009.

9. Borojevic, K. and Borojevic, K., The transfer and history of 'reduced height genes' (Rht) in wheat from Japan to Europe. $J$. Hered., 2005, 96, 455-459.

10. 'Norin 10 Wheat', https://en.wikipedia.org/wiki/Norin_10_wheat

11. 'Norman Borlaug', https://en.wikipedia.org/wiki/Norman_Borlaug

12. IARI, IARI Wheats: The Path to Plenty, Indian Agricultural Research Institute, New Delhi, 1996.

13. Khush, G. S., Coffman, W. R. and Beachell, H. M., The history of rice breeding: IRRI's contribution. In Rice Research and Production in the 21st Century: Symposium Honoring Robert F. Chandler, Jr. (ed. Rockwood, W. G.), International Rice Research Institute, Los Banos, Philippines, 2001, pp. 117-135.

14. Wheat Research in India - A Successful Journey, A report, ICARIndian Institute of Wheat and Barley Research, Karnal, India.

15. Li, J., Xin, Y. and Yuan, L., Hybrid rice technology development ensuring China's food security. International Food Policy Research Institute Discussion Paper, 00918, 2009.

16. Swaminathan, M. S., M.S. Swaminathan in Conversation with Nitya Rao: From Reflections on My Life to the Ethics and Politics of Science, Academic Foundation and M.S. Swaminathan Research Foundation, Chennai, 2015.

17. Chen, F. et al., The sequenced angiosperm genomes and genome databases. Front. Plant Sci., 2018; doi:10.3389/fpls.2018.00418.

18. Shao, Z.-Q. et al., Large-scale analysis of angiosperm nucleotide binding site-leucine-rich repeat genes reveal three anciently diverged classes with distinct evolutionary patterns. Plant Physiol., 2016, 170, 2095-2109.

19. Su, J., Spears, B. J., Kim, S. H. and Gassmann, W., Constant vigilance: plant functions guarded by resistance proteins. Plant J., 2018, 93, 637-650.

20. Meyer, R. S. and Purugganan, M. D., Evolution of crop species: genetics of domestication and diversification. Nature Rev. Genet., 2013, 14, 840-852.

21. Grover, A. and Pental, D., Breeding objectives and requirements for producing transgenics for major field crops of India. Curr. Sci., 2003, 84, 310-320.
22. Mayee, C. D. and Choudhary, B., Adoption and uptake pathways of $B t$ cotton in India, International Service for the Acquisition of Agri-biotech Applications (ISAAA): Ithaca, NY, USA, 2013; http://www.isaaa.org/programs/specialprojects/templeton/adoption/ india/India-Adoption \%20and\%20Uptake\%20Pathways.pdf

23. Chandrasekhara Rao, N., Pray, C. E. and Herring, R. J. (eds), Biotechnology for a Second Green Revolution in India, Academic Foundation, New Delhi, 2018.

24. Gould, F., Sustainability of transgenic insecticidal cultivars: integrating pest genetics and ecology. Annu. Rev. Entomol., 1998, 43, 701726.

25. Bates, S. L., Zhao, J.-Z., Roush, R. T. and Shelton, A. M., Insect resistance management in GM crops: past, present and future. Nature Biotechnol., 2005, 23, 57-62.

26. Padmanaban, G., Relevance of modern technologies to Indian agriculture. Curr. Sci., 2018, 114, 2432-2433.

27. Ellis, J. G., Lagudah, E. S., Spielmeyer, W. and Dodds, P. N., The past, present and future of breeding rust resistant wheat. Front. Plant Sci., 2014, 5, 641; doi:10.3389/fpls.2014.00641.

28. Krattinger, S. G. and Keller, B., Molecular genetics and evolution of disease resistance in cereals. New Phytol., 2016, 212, 320332.

29. NAAS, Resolution and report on GM mustard-National Academy of Agricultural Sciences, New Delhi, 2018; http://naasindia. org/Documents/GMmustard.pdf

30. Mariani, C., De Beuckeleer, M, Truettner, J., Leemans, J. and Goldberg, R. B., Induction of male-sterility in plants by a chimeric ribonuclease gene. Nature, 1990, 347, 737-741.

31. Mariani, C., Gossele, V., De Beuckeleer, M., De Block, M., Goldberg, R. B., De Greef, W. and Leemans, J., A chimaeric ribonuclease-inhibitor gene restores fertility to male sterile plants. Nature, 1992, 357, 384-387.

32. Pradhan, A. K., Sodhi, Y. S., Mukhopadyay, A. and Pental, D., Heterosis breeding in Indian mustard Brassica juncea (L. Czern \& Coss): analysis of component characters contributing to heterosis for yield. Euphytica, 1993, 69, 219-229.

33. Jagannath, A., Bandyopadhyay, P., Arumugam, N., Gupta, V., Burma, P. K. and Pental, D., The use of a spacer DNA fragment insulates the tissue-specific expression of a cytotoxic gene (barnase) and allows high-frequency generation of transgenic male sterile lines in Brassica juncea L. Mol. Breed., 2001, 8, 11-23.

34. Jagannath, A., Arumugam, N., Gupta, V., Pradhan, A., Burma, P. K. and Pental, D., Development of transgenic barstar lines and identification of a male sterile (barnase)/restorer (barstar) combination for heterosis breeding in Indian oilseed mustard (Brassica juncea). Curr. Sci., 2002, 82, 46-52.

35. Swaminathan, M. S., Report of the Task Force on Application of Agriculture Biotechnology by Dr M. S. Swaminathan, Ministry of Agriculture, Government of India, May 2004.

36. The World Food Prize, 2013; https://www.youtube.com/watch?v= Iwd5A_W1SRE

37. Fredrickson, D. S., Asilomar and recombinant DNA: the end of the beginning. In Biomedical Politics (ed. Hanna, K. E.), Institute of Medicine, National Academies Press, USA, 1991.

38. Genetically Engineered Crops: Experiences and Prospects, Committee on Genetically Engineered Crops: Past Experience and Future Prospects. 2016, National Academies Press, National Academy of Sciences, USA, 2016, ISBN 978-0-309-43738-7; http://www.nap.edu/catalog/23395/genetically-engineered-cropsexperiences-and-prospects.

39. AAAS, Statement by the AAAS Board of Directors on labeling of genetically modified foods. American Association for the Advancement of Science, USA, 2012; https://www.aaas.org/sites/ default/files/s3fs-public/AAAS GM statement.pdf

40. Genetically Modified (GM) Plants: Questions and Answers, The Royal Society, London, 2016; https://royalsociety.org/topics-policy/ projects/gm-plants/ 


\section{REVIEW ARTICLE}

41. Declaration of the 9th Annual Meeting of African Science Academies, 2013; http://www.eas-et.org/AMASA9 Doc/English\%20Declaration.pdf

42. EASAC Policy Report No. 21, The Science Advisory Council of the National Science Academies of the EU Member States, 2013, ISBN: 978-3-8047-3181-3; https://easac.eu/fileadmin/PDF s/reports statements/Planting the Future/EASAC_Planting the Future_FULL REPORT.pdf

43. AMA, Policy H-480.958 Bioengineered (Genetically Engineered) Crops and Foods, American Medical Association, USA, 2013; https://www.cga.ct.gov/2013/KIDdata/Tmy/2013HB-06527-R000305-AMA\%20Bioenginerred\%20Crops\%20and\%20Foods-TMY. PDF

44. Are There Health Hazards for the Consumer from Eating Genetically Modified Food? Union of the German Academies of Science and Humanities, Foundation for Biotechnology Awareness and Education (FBAE), 2006; http://www.fbae.org/2009/FBAE/ website/special-topics are there health hazards.html

45. A Decade of EU-funded GMO Research (2001-2010), Report of the European Commission; https://ec.europa.eu/research/biosociety/pdf/a decade of eu-funded gmo research.pdf

46. Lynas, M., Seeds of Science: Why We Got it so Wrong on GMOs, Bloomsbury Sigma, UK, 2018.

47. Nabhan, G. P. and Wilson, K., Where Our Food Comes From: Re tracing Nikolai Vavilov's Quest to End Famine, Island Press, Washington DC, USA, 2011.
48. https://en.wikipedia.org/wiki/Trofim_Lysenko

49. Sussex, I., The scientific roots of modern plant biotechnology. Plant Cell, 2008, 20, 1189-1198.

50. Jiao, W-B. and Schneeberger, K., The impact of third generation genomic technologies on plant genome assembly. Curr. Opin. Plant Biol., 2017, 36, 64-70.

51. Smil, V., Enriching the Earth: Fritz Haber, Carl Bosch, and the Transformation of World Food Production, MIT Press, Boston, USA, 2004.

52. Marks, R. B., The Origins of the Modern World: A Global and Environmental Narrative from the Fifteenth to the Twenty-first Century, Rowman \& Littlefield, Maryland, USA, 2015.

53. Devereux, S., Famine in the Twentieth Century, Institute of Development Studies, University of Sussex, UK, 2000; https:// www.ids.ac.uk/files/dmfile/wp105.pdf

54. Global Hunger Index: The Inequalities of Hunger, Report, International Food Policy Research Institute, Washington DC, USA, 2017; http://ebrary.ifpri.org/utils/getfile/collection/p15738coll2/id/ 131422/filename/131628.pdf

Received 7 January 2019; accepted 16 August 2019

doi: $10.18520 / \mathrm{cs} / \mathrm{v} 117 / \mathrm{i} 6 / 932-939$ 